\title{
Culture-led strategies for urban regeneration: a comparative perspective on Bilbao
}

\begin{abstract}
Culture is used as a development strategy in many European cities, a means to attract capital, to improve the image of the city, and to promote unity and co-operation. Like other strategies it has winners and losers and, in its symbolic meanings, may provoke conflict.
\end{abstract}

\section{Key Words}

Urban regeneration. Culture. Postindustrial cities.

\section{Michael Keating and Monika de Frantz}

\section{Urban competition and growth coalitions}

Since the 1980s, economic development has become a principal preoccupation of European cities. Increasingly, economic development is seen as a competitive matter, in which cities struggle for advantage in national and international markets. This marks a break from the postwar years, in which cities were integrated into national economies, planning systems and welfare states, which themselves assumed the obligation to maintain some sort of territorial balance. Yet it recalls earlier eras in the early modern period or the nineteenth century, when urban leaders had more autonomy and showed a certain entrepreneurship and awareness of the need to position themselves strategically (Le Gales 2002). It also invites comparison with the United States, where the idea of cities competing is a staple of the literature on urban politics (Kantor 1987; Sanders \& Stone 1987).

Cities compete for investment, for jobs, for tax base, for visitors, and for state subsidies. In a less clearly defined sense, they also compete for visibility and prestige. In the United States, where there are fewer restrictions on the part of central (or state) government, they spend relatively freely on subsidies, tax breaks, partnerships and other special deals for corporations and other investors. European cities, which generally have less fiscal autonomy, are deprived of these financial instruments, but at the same time more protected from demands for investor subsidies at the taxpayers' expense (Keating 1993). However, European economic integration and pressures on national welfare state expenditures increase urban competition here as well. This leads urban leaders to follow the example of the US and seek other means for stimulating investment and attracting mobile capital.

Yet, it is not by any means clear that they are obliged to do so, or that their efforts to attract capital in practice achieves the expected returns. The economic competitiveness paradigm that depicts cities as condemned to compete in a war of 'all against all' to attract limited investment makes a number of questionable assumptions. First, it assumes that cities as local polities are productive units, with an internal logic and cohesion, which can then compete against each other (Porter 1990). There is some evidence from contemporary literature that local production systems are indeed becoming more important and that the economic actors within them may enhance their competitive advantage by pooling resources, and co-operating in the production of public goods (Storper 1997). It is, however, a large leap from this reasoning to assume that a city, which is primarily a political unit, is also a productive unit in competition with others. Second, the model assumes that the city has a unitary interest in growth (Peterson, 1981). 
This is a reification, which disguises the fact that the various groups within the city may have different interests in distinct growth strategies. Growth policies may not even be Pareto optimal in the sense of making some people better off without harming anyone else; they tend to come with very definite and identifiable costs. Third, there is an assumption that a more entrepreneurial city government can make a difference in economic fates (Hubbard and Hall 1998). This is often untestable, since we cannot know what would have happened in the absence of growth policies. Yet growth policies have the curious advantage that politicians will always gain politically from them, whether they work or not. If the city grows and there is a growth policy, the politicians can take credit for the growth. If it grows and they do not have a policy, they cannot take credit. If there is no growth and they have no policy, they will be blamed for inactivity. If there is no growth and they have a policy, they can show that they are addressing a serious problem. By making external circumstances such as globalization pressures, urban competition, or institutional restraints by state authorities responsible for their failure, they can justify their claims for urban autonomy and thus increase their own political power base. Therefore we should rather see the theme of urban competition, and the associated neo-mercantilist vision of cities vying for limited opportunities, as constructed by political and economic elites in order to mobilize support behind particular policy stances.

Economic development policies do not, then, stem from an objective requirement imposed by cities' geo-economic circumstances. They are a political construction, which are attractive to politicians in an age of declining class alignments, allowing them to predicate a unitary city interest and thus to extend their potential electoral constituency to the entire population (Keating 1993). The theme of competition is a highly ideological notion, imported from the market and now incorporated by governments into all manner of fields, including urban development, the arts, universities and public services. It, too, serves to rally political support by postulating a conflict of interest between the unitary city, represented by the political elites, and the other, in the form of other cities. The American urban politics literature has been very good in deconstructing the role of these elites and showing how the city interest has in practice been shaped by their partisan interests organized in development coalitions or 'growth machines' (Logan and Molotch 1987; Sanders and Stone 1987).

Economic development policies have always shown an uneven impact within cities. They tend to increase social inequality, as some groups and neighbourhoods do well and others suffer. The idea that growth will generate a surplus to be used to compensate the losers is only partly sustained, since pro-investor policies need to be sustained in order to maintain the growth path. There is also an increase in inequalities between cities, as some are better placed to take advantage of global opportunities. This in turn sharpens old social and political divisions and produces new ones. The transition from manufacturing to service industries, has a differential impact on the fortunes of groups by sector, class, gender and location. Urban renewal, which has often concentrated on gentrifying city centres and run-down industrial districts by bringing back business and the middle classes, may price lower income residents out of their neighbourhoods. Conservation policies may increase the wealth of affluent property owners. Urban renewal may destroy old communities, with their social and political networks. Economic development may have negative environmental consequences. Small, local businesses may be upset by the arrival of better-resourced competitors with access to outside capital. Investment in economic development may divert expenditure 
away from social or cultural priorities. Not surprisingly, then, development policies, originally predicated on a unified city interest and a broad appeal, are often divisive and bring into being contestatory social and political movements, with their own competing visions of the urban future (Castells 1983); these include Greens and non-governmental organizations which become centres for resistance (Bianchini 1993) as well as aggressive right-wing populist parties (de Frantz 2003).

To overcome these oppositions urban regeneration policies need strong leadership with a large degree of autonomy (Judd 2000). This is often a charismatic mayor, but it may also be provided by development agencies, run by technical elites or linked to sections of the business community. This, indeed, motivated the establihsment of Urban Development Corporations in England and Wales under the last Conservative central government as well as the Scottish Development Agency (SDA) by the Scottish Office. Alternatively, leadership may be provided by a strongly entrenched local political elite, such as a party machine. Machine politics, rooted in patronage and clientelism and the distribution of divisible goods, is often seen as inimical to an efficient implementation of development politics. Yet, once committed to the new politics, it may be able to deliver. Glasgow in adopting its post-industrial strategy in the 1980s and 1990s owes a lot to the dominance of a small policy elite within the Labour group (Keating, 1988). Vienna's Social Democratic party machine, first established in the 1920s, remains strong despite its reorientation towards the private sector since the early 1990s, during which it has struggled more with its own bureaucracy than with a coherent political opposition. By contrast, Berlin's former CDU party-machine, after managing the first years of transition, broke down in 1999 leaving a political vacuum. It is ironic that political machines as typical products of the age of the unionized, industrial economy may be the vehicles for delivering post-modern and post-industrial urban strategies.

\section{Culture as a Development Tool}

Some European cities have utilized culture, such as museums, galleries, and festivals as a development tool. This has certain apparent advantages. Culture can attract visitors, especially from more affluent classes, who stay only a short while and make few demands on public services. It taps into an expanding sector, linked to the leisure economy. Cultural policy can change the image of the city, an important consideration in declining industrial cities like Glasgow and Bilbao, so serving as a marketing tool. In a crowded international market, it can mark the city as distinct, giving it a brand image. This can indirectly promote its economic competitiveness by increasing its position in the quality life indexes of international investment rankings. It may also have a psychological effect within the city, building self-confidence and civic pride among the population and even boosting optimism among investors. This positive image building might even distract voters' attention from more serious social or economic problems in the city. By promoting a climate of creativity and individual entrepreneurship, the cultural sector may contribute to the development of small and medium enterprise as a locally bound social capital. Thus culture-led regeneration offers many attractions for policy-makers (Bianchini 1993; Zukin 1995).

Bilbao, like other old industrial cities, notably Glasgow, has used cultural regeneration as part of a broader economic development strategy that aimed to replace the city's devastated industrial base with a booming service sector. As well as its direct effects, this is intended to reconstruct the negative image associated with deindustrialization by promoting a 'post-industrial' image (Gomez 1998). The existence 
of a historic city core and nineteenth century architectural legacy from the years of industrial growth is a key asset complementing the symbolic effects of Frank Gehry's Guggenheim museum. Thus tourism can be promoted (Plaza 1999), but the comparative experience shows the costs of such image reconstruction (Gomez 1998; Gonzalez and Gomez 2001). Glasgow had to sell off its industrial development sites to finance its year as European City of Culture. Visitors then tend to be short term, often staying only a day and not always spending large amounts of money. Therefore local cultural production does not necessarily benefit from such globally oriented image strategies. Also poor cities are in a weak position when negotiating with outside investors such as the global corporation Guggenheim. So the economic effects from cultural regeneration are often reduced to direct consumption effects rather than profiting more productive and employment intensive local sectors.

With regard to the question of the uniqueness of the cultural investment, there is probably a first mover advantage, which Glasgow and Bilbao have exploited, in that they have occupied their respective niches at an early stage. In Vienna, an old culture city, the sudden international fame of the 'cultural newcomer' Bilbao spurred a competitive response. Tourism managers and politicians felt that Vienna's historic heritage and high culture was not enough to maintain its worldwide reputation. In the emerging cultural competition among cities, city marketing started to incorporate associations with innovation, creativity, and entrepreneurship to be transmitted only by a new cultural flagship, the 'Museumsquartier'. There the match of existing historic artefacts and neighbourhoods with ultra-modernism in art and new design created a locally specific blend of tradition and modernity, of stability and dynamism. Yet compared to media coverage of the 'cultural newcomer' Bilbao, created almost independently of any existing cultural image, Vienna's leaders considered historic heritage almost as a handicap for its marketing strategy (de Frantz 2003). Berlin's construction of the Potzdamer Platz in the early Nineties followed a similar symbolic cultural marketing strategy to symbolize its economic rebirth after decades of partition. However, the subsequent financial meltdown of Berlin's municipality showed the political and economic consequences of cultural regeneration without a real economic base. Still Berlin, like Vienna, can refer to its unquestionably unique historic heritage that makes its cultural profile less dependent upon the success of flagship projects and global investors. Although old industrial cities like Bilbao can also build on an existing cityscape and cultural legacy derived from their pre-industrial past and the era of industrial prosperity, their fame depends more on the single flagship.

Economic development policy is a potentially contentious and divisive issue, although sold as a shared policy that benefits everybody. This is brought into even sharper relief in the case of cultural policy, with its multiple meanings and deep symbolisms. Cultural artefacts, buildings and performances relate to a past, a present and a future that are always contested and invested with new meanings (Tunbridge and Ashworth 1996). As Bianchini notes (1993), the political objectives associated with culture confront urban decision-makers with a strategic choice, particularly as the emerging economic paradigm adds up to and increasingly covers other, pre-existing socio-cultural priorities. Around the time of Glasgow's year as European City of Culture, a row broke out over the People's Palace on Glasgow Green, a site sacred to working class and labour traditions. Another conflict arose over plans to redevelop the Green itself, given its history as the gathering place of labour and radical movements. Visitors entering County Durham in North East England are greeted by a sign welcoming them to 
the Land of the Prince Bishops, this mediaeval reference blotting out the region's better known legacy of coal mining and heavy industry. On the coast is the town of Hartlepool, where we will find the Historic Quay, in fact a building completed in the early 1990s outside the old docks, and evoking the history of the slave trade among other things. The fact that the slave trade was conducted on the west coast, and not from Hartlepool, seems beside the point. We can all feel a sense of righteous indignation about an event sufficiently remote. Memories of the actual history of the area as a coal field evoke too recent memories of the industrial strife of the 1970s and 1980s and the moral lesson is altogether more contested; so this is excised from the history. In the same region, gigantic iron sculpture, the Angel of the North, was built in the old shipyards of Hartlepool, linking to the past, but has become the focus for all manner of symbolic interpretations, from the decline of the sturdy industries of the past, to the suggestion that the wings recall a second world war Luftwaffe bomber.

The manipulation of historic heritage for economic development is a favored instrument of tourism marketing, but it can cause a conflict between external representation and internal mobilization (Kearns and Philo 1993). Vienna's population is divided between pride and indignation over the way their tourism industry markets the city's heritage to the world. Locals feel alienated by the 'museumfication' of their city centre that tends to prioritize aesthetic beauty over functionality and tourism over local needs. The status of Vienna's historic center as UNESCO world heritage has raised questions about the extent to which monumental protection inhibits present-day creativity, indigenous development and real estate investment. Discussions of the historic heritage also opened up deeper conflicts over collective memories and national identities associated with Austria's history of two lost world wars and the decline of the Habsburg empire (de Frantz 2003). The conflict-loaded meanings associated with urban culture are even more apparent in the reconstruction of Berlin's centre with its multiple memorials of German nation-building, idealist humanism, National Socialism, Communism and Europe's Cold War division (de Frantz 2002).

Regional histories are equally sensitive. Barcelona's Museum of the Catalan People, has an underlying nationalist message, about the progress of Catalonia, its oppression under successive regimes and its rebirth after the transition to democracy. Edinburgh's Museum of Scotland is less overtly nationalistic, but there is a similar teleology, as the history of 'Scotland' is started in the prehistoric era and taken up to modernity. Such was the sensitivity of the national issue in the 1990s, however, and the reluctance to essentialize modern Scottish culture that the top floor, representing Scotland since the 1970s, is a mere lumber room of odd items donated by prominent Scots with no discernible message at all. In the case of Bilbao the new global symbolism of the Guggenheim links up with strong nationalist ambitions, as the promotion and protection of Basque identity traditionally represented the main concern of regional and local cultural policies (Gonzalez 1993).

In socially segregated cities, the location of cultural spaces and events is equally contentious. Edinburgh's Festival has regularly been criticized for being largely confined to the city centre. Glasgow's rival Mayfest, launched in the 1980s, was intended as a conscious contrast, taking culture to the poorer quarters. The Citizens' Theatre has remained in its Gorbals base, despite plans in the 1980s to move it to a cultural complex in the city centre. In Vienna, the location of the new Museums Quarter caused conflict between the city government's desire for a symbolic upgrading of the working class areas at the Eastern side of the Danube river and the federal state's plans for a cultural symbol 
complementing the state institutions and tourism attractions in the center of the capital city. In Berlin the construction of the Potzdamer Platz and the plans for the reconstruction of the former Castle aimed to overcome the city's partition through creating a new centre as a shared symbol of reunification (de Frantz 2002).

There is a recurring battle over the importance of 'highbrow' versus 'lowbrow' culture and whether the distinction itself makes any sense. There is in the Labour movement in Scotland, as in other parts of Europe, a strong belief that 'highbrow' culture is not something exclusively for the middle classes but should be available to all. This explains the Labour Party's traditional opposition to admission charges for museums. The issue was particularly controversial when Glasgow's Burrell collection was opened in the 1980s in Pollok Park. Although it was promoted as a tourist attraction (and was a key event in Glasgow's transition to a cultural development strategy) the city council insisted that entry should be free. Berlin, following the working class state culture imposed upon the Eastern part by the past Communist government, has now dedicated its centre to relatively broadly accessible high culture consumption. In Vienna, a long tradition of Social Democratic cultural education is now being challenged by a conservative federal government. But despite the multiple social-political expectations associated with cultural policies, the issue is largely discussed among elites, while little addressing the tastes and cultural interests of the masses.

For Bilbao, Gonzalez (1993) identified two competing cultural visions within the population. The first, of a 'European capital' attracting investment, tourists and business visitors to the centralized services of a region and symbolized by a large cultural district was realized through the Guggenheim complex. The second is based on indigenous strengths meeting the needs of local residents, including deprived areas, through the decentralization of services and small, manageable and well distributed cultural facilities. This would link up economic objectives with pre-existing cultural policies associated with Basque identity politics and local working class culture. In the absence of better economic alternatives, Bilbao's politicians chose the global development version, which no doubt offers economic advantages at least for some parts of the urban population. Yet urban leaders attempting to impose a cultural consensus upon the plural meanings of their city often lose control of the resulting symbolic conflicts. Instead of promoting a unitary image of the city externally and internally, cultural regeneration strategies can have the opposite effect. In particular where the image of social harmony and economic success differs greatly from the economic reality, it is difficult to turn cultural investments into economic profit.

\section{Conclusion:}

Following the growth paradigm, urban politicians increasingly adopt public-private partnerships and growth strategies. They thus hope to increase the financial resources available for urban development, reduce dependence on state government and bureaucracy, and promote private entrepreneurship. The result is smaller, more autonomous, flexible, and informal forms of urban 'governance' but the potential for citizen participation, civic engagement, and the political responsiveness associated with local democracy remains limited. The competitive imperative, rather, enhances the role of local leadership and raises questions of political accountability and equality of representation. It also brings out new social and economic conflicts.

Cultural regeneration is an even more problematic strategy due to the multiple and contested meanings associated with urban symbols. Cultural flagships cannot represent a 
prototype to be duplicated successfully in different locations and contexts. Dependent on the opportunities given for political participation and cultural self-expression, culture can serve both as a powerful catalyst for economic regeneration and as a source of political controversy over the future of the city. It might also serve to smother conflicts with a superficial pro-growth consensus while serving the interest of a small elite. While it is difficult to measure the economic returns from the symbolic effects of cultural strategies, in Bilbao the construction of the Guggenheim museum has definitely changed the city's image. By turning the city's regeneration efforts into a global spectacle, it created a cultural model for other cities' development plans. Moreover, the drastic contrasts between the Guggenheim's global culture and the city's deindustrialized context initiated discourse at the global as well as at the local level about the role of politics in the relationship of economy and culture.

\section{References:}

Bianchini, Franco (1993) 'Remaking European cities: the role of cultural policies', in: Franco Bianchini; Michael Parkinson (eds.) Cultural policy and urban regeneration: the West European experience, Manchester: Manchester University Press.

Castells (1983) The city and the grassroots - a cross-cultural theory of urban social movements, London: Arnold.

De Frantz, Monika (2003) 'Cultural regeneration as discursive governance: the political debate about the new Vienna museum quarter', EURA Eurocities Conference, Budapest, August 2003

De Frantz, Monika (2003) 'Multi-level urban culture: identifying the new capital city through different spatial conceptions of its center - the Palast der Republic / Stadtschloss in Berlin', Second EuroConference "The European City in Transition", Bauhaus University Weimar, November 2002 (forthcoming, Peter Lang)

Gomez, Maria (1998) 'Reflective images: The case of urban regeneration in Glasgow and Bilbao’, International Journal of Urban and Regional Research, 22 (1): 106-121

Gomez, Maria and Sara Gonzalez (2001) 'A Reply to Betriz Plaza's “The GuggenheimBilbao Museum Effect', International Journal of Urban and Regional Research, 25 (4): 898-900

Gonzalez, Julia (1993) 'Bilbao: culture, citizenship and quality of life', in: Franco Bianchini and Michael Parkinson (eds.) Cultural policy and urban regeneration: the West European experience. Manchester: Manchester University Press.

Hubbard, Phil and Tim Hall, (1998) 'The Entrepreneurial City and the "New Urban Politics"', in: Tim Hall; Phil Hubbard (eds.) The entrepreneurial city. Geographies of politics, regime and representation, West Sussex: John Wiley.

Judd, Dennis (2000), ‘Strong Leadership’, Urban Studies, 37 (5-6): 951-961 
Kantor, Paul (1987), 'The dependent city. The changing political economy of urban economic development in the United States’, Urban Affairs Quarterly, 22 (4): 493-520

Kearns, Gerry and Chris Philo, (1993), 'Culture, history, capital: a critical introduction to the selling of places, in Gerry Kearns and Chris Philo (eds.) Selling places. The city as cultural capital, past and present, Oxford: Pergamon Press.

Keating, Michael (1988). The city that refused to die: Glasgow: the politics of urban regeneration, Aberdeen: Aberdeen University Press.

Keating, Michael (1993), 'The Politics of Economic Development. Political Change and Local Development Policies in the United States, Britain, and France', Urban Affairs Quarterly, 28 (3): 373-396

Le Gales, Patrick (2002), European cities. Social conflicts and governance, Oxford: Oxford University Press.

Logan, John; Molotch, Harvey (1987), Urban fortunes: the political economy of place, Berkeley: University of California Press.

Peterson, Paul (1981), City Limits, Chicago: University of Chicago Press

Plaza, Beatriz (1999), 'The Guggenheim-Bilbao Museum Effect: Reply to Maria V. Gomez' "Reflective Images: The case of urban regeneration in Glasgow and Bilbao"', International Journal of Urban and Regional Research, 23 (3): 589-592

Porter, Michael (1990), The competitive advantage of nations, London: Collier Macmillan.

Sanders, Heywood and Clarence Stone, (1987), 'Developmental politics reconsidered', Urban Affairs Quarterly, 22 (4): 521-539

Storper, Michael (1997), The regional world: territorial development in a global economy, New York: Guilford Press.

Tunbridge, John and G.J. Ashworth, (1996), Dissonant heritage: the management of the past as a resource in conflict, Chichester: John Wiley.

Zukin, Sharon (1995), The Cultures of Cities, Oxford: Blackwell.

\section{The authors:}

Michael Keating is Professor of Regional Studies at the European University Institute, Florence and Professor of Scottish Politics at the University of Aberdeen.

Monika de Frantz is Researcher at the Department of Social and Political Sciences, European University Institute, Florence, working on urban studies, political identity mobilization, and European integration. 